How to cite: Tudorache, A.-V. (2019) Current Possibilities for Elaborating Flash Flood Warnings in Romania. Case Study: the Flood Produced on 30 June 2018 in the Trotuş River Basin. 2019 "Air and Water - Components of the Environment" Conference Proceedings, Cluj-Napoca, Romania, p. 163-172, DOI: 10.24193/AWC2019 16.

\title{
CURRENT POSSIBILITIES FOR ELABORATING FLASH FLOOD WARNINGS IN ROMANIA. CASE STUDY: THE FLOOD PRODUCED ON 30 JUNE 2018 IN THE TROTUȘ RIVER BASIN
}

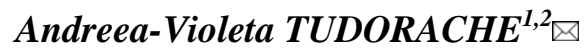 \\ DOI: 10.24193/AWC2019_16
}

\begin{abstract}
This paper concentrates information on the flash flood produced on 30 June 2018 in the Trotuş River basin. Flash floods are extreme phenomena, caused by torrential rainfall, occurring in a very short time in small hydrographical basins without being hydrometric monitored. These phenomena occur with increasing frequency and severity in the last decades both worldwide and in our country and can be manifested in almost any hydrographic area. Thus, in order to diminish the negative effects caused by floods, an important activity is forecasting and warning in case of dangerous hydrological events. Hydrological warning messages are issued with a certain amount of anticipation time, allowing the officials in the field of emergency management to take the necessary measures to protect people's lives and assets, as well as socio-economic objectives. In the operative procedure for elaborating flash floods warnings, the following informations are used from: national network of hydrometric stations, meteorological radar products, Romanian Flash-Flood Guidance System (ROFFG), South East European Flash-Flood Guidance System (SEEFFG), European Flood Awareness System (EFAS). The purpose of this paper is to present the mail informations used in operative procedure to elaborate flash flood warnings, analyzing the case study on the event produced on 30 June 2018 in the Trotuş River Basin.
\end{abstract}

Keywords: Flash Floods, Forecasts, ROFFG, SEEFFG, EFAS

\section{INTRODUCTION}

Climate change and global warming are complex topics of great importance, studied with interest at national and international level (Ardelean, 2008, Solomon et al., 2009, Trenberth, 2007). Climate variability, caused by hot air advections of different origins, is also manifested in the Trotuș River basin, with negative economic and social consequences. The maximum flow is mainly determined due to the abundant precipitation and snow melting water. Among the determining factors can be mentioned: the climate, the surface and shape of the hydrographic basin, the soil, the use / coverage of the land, etc. (Roșu, 1973; Pișota et al., 2005).

${ }^{1}$ Faculty of Geography, University of Bucharest, 1 Nicolae Bălcescu Blvd., Sector 1, 010041, Bucharest, Romania, e-mail: tudoracheav@gmail.com

${ }^{2}$ National Institute of Hydrology and Water Management, 97 E Bucuresti-Ploiești St., Sector 1, 013686 , Bucharest, Romania. 


\section{GENERAL GEOGRAPHICAL CHARACTERISTICS OF THE TROTUȘ RIVER BASIN}

Trotuș is a river with a length of $162 \mathrm{~km}$, which is located in the eastern part of Romania. It springs from the Ciuc Mountains, at an altitude of $1380 \mathrm{~m}$, and flows into the Siret River crossing the Bacău and Vrancea counties. The hydrographical basin, with an area of $4456 \mathrm{~km}^{2}$ (Fig. 1) overlaps the central-eastern part of the Eastern Carpathians and the Sub-Carpathians of Moldova.

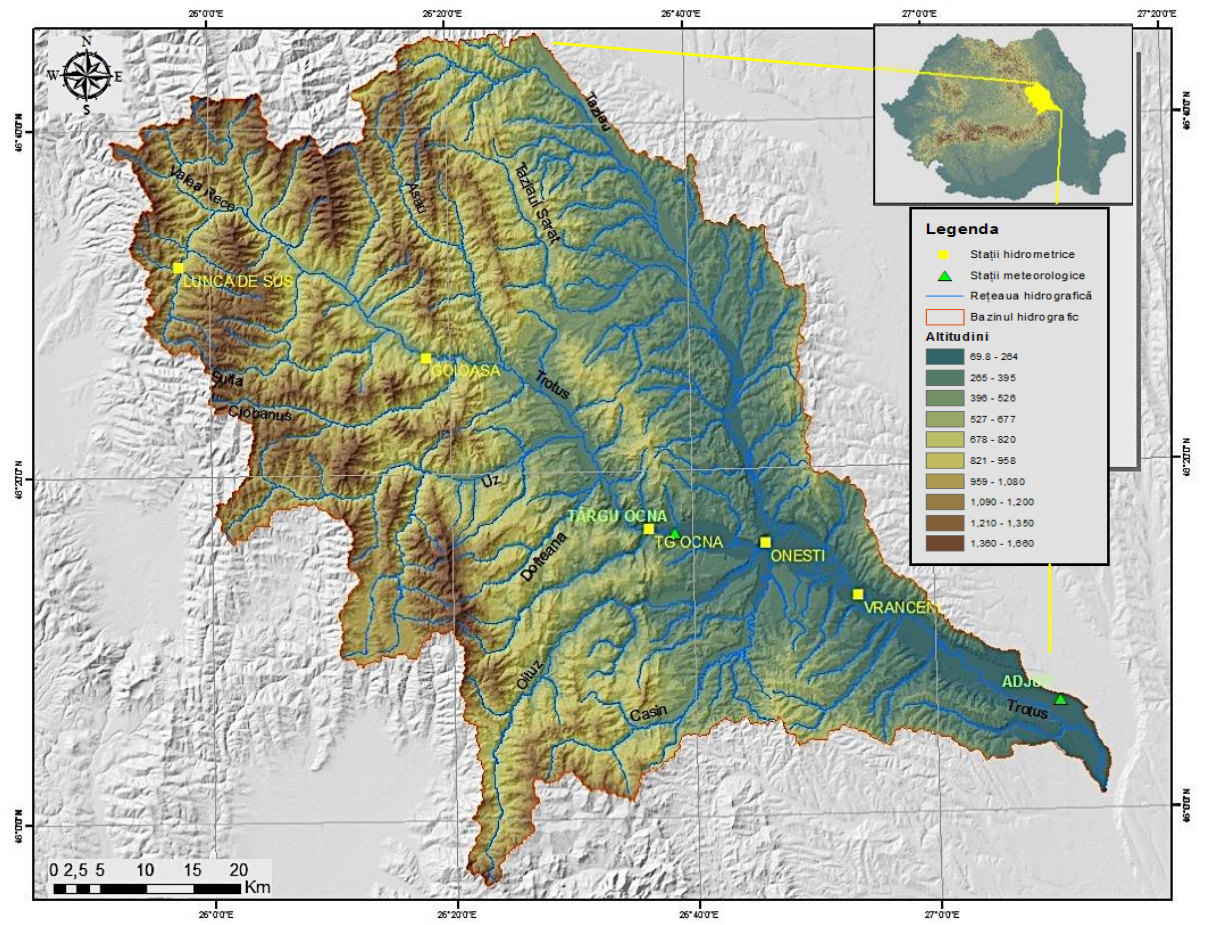

Fig. 1. Trotuș River basin - hydrographic network

This development influenced the evolution of the Trotuş hydrographical basin by giving it specific morphological and morphometric features (Roșu, 1973). The relief, due to its geomorphometric features (altitude, relief, relief fragmentation density etc.), has a major influence on the formation of water resources and on the reception, accumulation and control conditions of rainfall and snow melting.

Table no. 1 presents some main morphometric data on the analyzed river basin.

Table 1. Morphometric data, Trotuș River (source: Atlasul Cadastrului Apelor din România, 1992)

\begin{tabular}{|c|c|c|c|c|c|c|c|}
\hline \multirow{2}{*}{$\begin{array}{l}\text { Lenght } \\
(\mathrm{km})\end{array}$} & \multicolumn{3}{|c|}{ Altitude (m) } & \multirow{2}{*}{$\begin{array}{l}\text { Average } \\
\text { slope (\%) }\end{array}$} & \multirow{2}{*}{$\begin{array}{l}\text { Sinuosity } \\
\text { coefficient }\end{array}$} & \multirow{2}{*}{$\begin{array}{c}\mathrm{A} \\
\left(\mathrm{Km}^{2}\right)\end{array}$} & \multirow{2}{*}{$\begin{array}{c}\text { Forest } \\
\text { found } \\
\text { area (ha) }\end{array}$} \\
\hline & Upstream & Downstream & Average & & & & \\
\hline 162 & 1380 & 79 & 706 & 8 & 1.54 & 4456 & 241737 \\
\hline
\end{tabular}

Note: $\mathrm{A}=$ area 
From the spring to the confluence with Siret, Trotus receives the following important tributaries: on the left: Asău, Tazlău and on the right: Sulța, Ciobănuș, Uz, Dofteana, Oituz and Caşin (Fig. 1).

\section{DATA AND METHODS}

This paper presents an analysis of the current possibilities for elaborating flash floods warnings, using as a case study the flood produced on 30 June 2018 in the Trotuş River basin. The operative procedure for elaborating flash floods warnings is based on:

- Precipitation rates estimated/measured in the National hydrometric and meteorologic station networks registered during the analyzed period, used in the operative activity for real time validation of radar precipitation.

- Weather radar products (precipitaion amounts recorded in real time, rainfall accumulations of 1 to 3 hours, predicting the direction of movement of cloud systems which generate heavy rains).

- Romanian Flash Flood Guidance System products (ROFFG).

- $\quad$ South Eastern European System Flash Flood Guidance products (SEEFFG).

- European System Flood Awarness products ( EFAS).

- Floods recorded at five representative hydrometric stations from Trotuș river basin: H.S. Vranceni, H.S. Onesti, H.S. Tg. Ocna, H.S. Goioasa, H.S. Lunca de Sus.

- Other data used to complete the study are the reports of damages received from the territory.

- In order to process the data, the following software packages were used: GIS, EXCEL and CAVIS - to determine the specific elements of the flood wave.

Data from five representative hydrometric stations within the basin: Lunca de Sus, Goioasa, Tg. Ocna, Oneşti, Vrânceni were analyzed (Table 2).

Table 2. Morphometric and hydrological data on the maximum flow of the Trotuş River at five hydrometric stations (data source: INHGA database)

\begin{tabular}{|c|c|c|c|c|c|c|c|c|c|c|c|c|}
\hline$\stackrel{\bar{D}}{\alpha}^{\bar{\alpha}}$ & $\dot{\text { Ḋ }}$ & $\begin{array}{c}\mathrm{A} \\
\mathrm{Km}^{2}\end{array}$ & $\begin{array}{c}\mathrm{H} \\
\text { med } \\
\mathrm{m}\end{array}$ & $\begin{array}{l}\text { Q.A. } \\
\mathrm{m}^{3} / \mathrm{s}\end{array}$ & $\begin{array}{l}\text { Q.I. } \\
\mathrm{m}^{3} / \mathrm{s}\end{array}$ & $\begin{array}{l}\text { Q.P. } \\
\mathrm{m}^{3} / \mathrm{s}\end{array}$ & $\begin{array}{c}\mathrm{Q} \\
\max \\
30.06 . \\
2016 \\
\end{array}$ & $\begin{array}{c}\text { Hmax } \\
30.06 . \\
2016\end{array}$ & Obs. & $\begin{array}{l}\text { C.A. } \\
\mathrm{cm}\end{array}$ & $\begin{array}{l}\text { C.I. } \\
\mathrm{cm}\end{array}$ & $\begin{array}{l}\text { C.P. } \\
\mathrm{cm}\end{array}$ \\
\hline \multirow{5}{*}{ 点 } & $\begin{array}{l}\text { Lunca } \\
\text { de Sus }\end{array}$ & 89.2 & 1140 & 6 & 15.6 & 34 & 25 & 150 & $\begin{array}{l}+30 \\
\text { C.I. }\end{array}$ & 80 & 120 & 200 \\
\hline & Goioasa & 765 & 1052 & 168 & 246 & 416 & 133,5 & 175 & - & 200 & 250 & 350 \\
\hline & $\begin{array}{l}\text { Tg. } \\
\text { Ocna }\end{array}$ & 2091 & 924 & 305 & 590 & 740 & 512 & 324 & $\begin{array}{l}+74 \\
\text { C.A. }\end{array}$ & 250 & 350 & 400 \\
\hline & Onești & 2836 & 830 & 457 & 641 & 1256 & 959 & 460 & $\begin{array}{l}+60 \\
\text { C.I. }\end{array}$ & 350 & 400 & 500 \\
\hline & Vrânceni & 4077 & 734 & 797 & 1175 & 2220 & 2402 & 520 & $\begin{array}{l}+20 \\
\text { C.P. }\end{array}$ & 350 & 400 & 500 \\
\hline
\end{tabular}

Note: H.S. = hydrometric station, $\mathrm{A}=$ area; $\mathrm{H}$ med = the average altitude of the river basin; $\mathrm{Q} . \mathrm{A}$. = flow of attention; Q.I. = flood flow; Q.P. = risk flow; Q $\max =\operatorname{maximum}$ flow; $\mathrm{H} \max =\operatorname{maximum}$ level; C.A. = attention level; C.I. = flooding level; C.P. = danger level. 
Data on the precipitations recorded during the analyzed period were, also, studied (Table 3).

Table 3. The amounts of rainfall accumulated during 28-30.06.2018 in Trotuș River basin (data source: INHGA)

\begin{tabular}{|c|c|c|c|}
\hline Hydrometric station & $\begin{array}{c}\text { Precipitations } \\
\text { 1/sqm }\end{array}$ & $\begin{array}{c}\text { Recording } \\
\text { period }\end{array}$ & $\begin{array}{c}\text { Mean precipitation } \\
\text { in Siret basin - } \\
\text { Bacau county }(1 / \mathbf{s q m})\end{array}$ \\
\hline Gura Văii & 105,5 & \multirow{10}{*}{$28-30.06 .2018$} & \multirow{10}{*}{125,3} \\
\hline Lucăcești & 167 & & \\
\hline Scorțeni & 148,5 & & \\
\hline Asău & 123,5 & & \\
\hline Cireșoaia & 137,8 & & \\
\hline Haloș & 140,7 & & \\
\hline Măgura & 134,7 & & \\
\hline Bacău (Bârnat) & 51,6 & & \\
\hline Cremenea & 121,9 & & \\
\hline Ferăstrău & 121,7 & & \\
\hline
\end{tabular}

The montly amount of precipitations in Romania, in June 2018 is shown in the map below (Fig. 2).

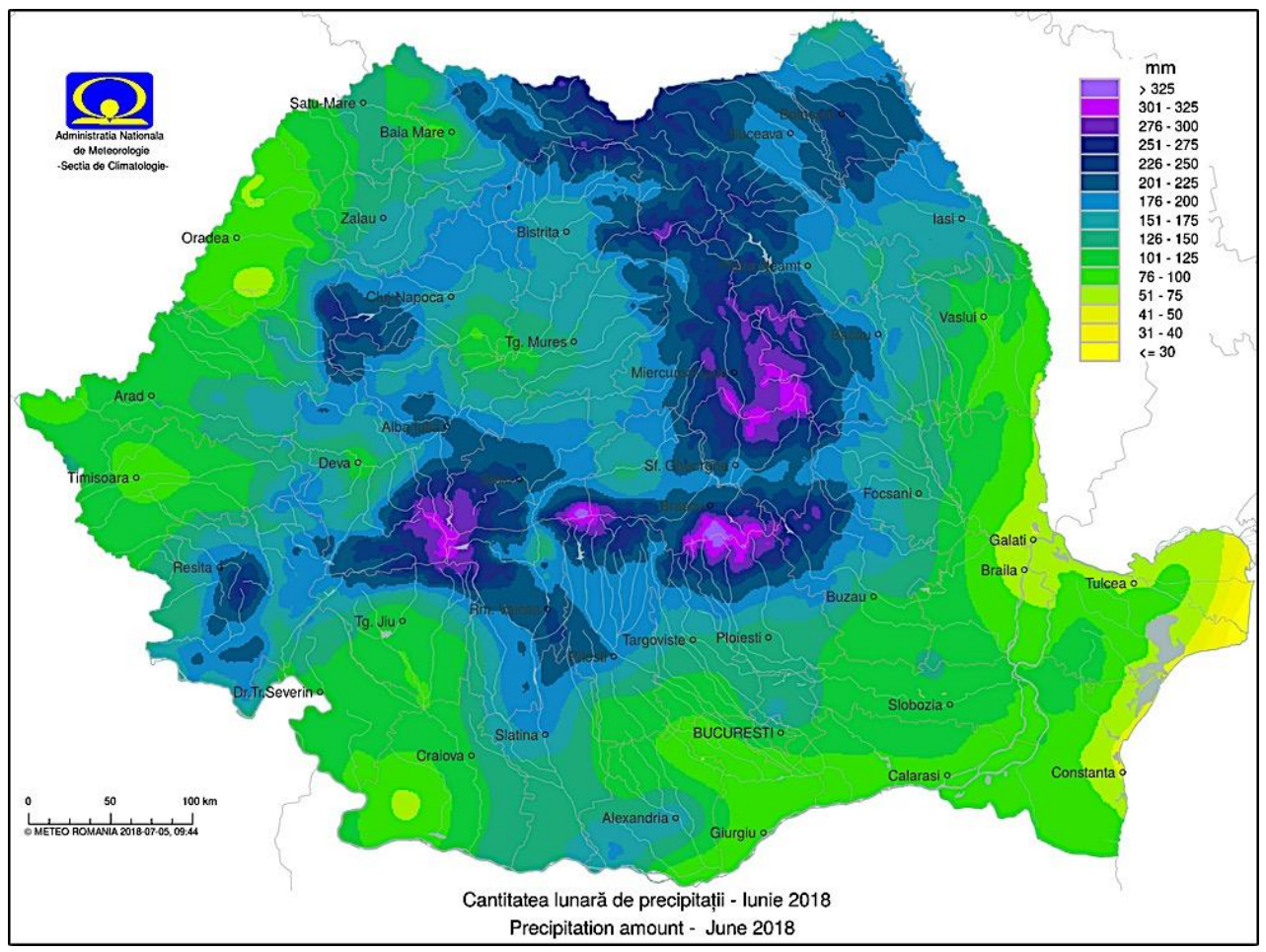

Fig. 2. Precipitation amount in Romania - June 2018 (data source: ANM)

The total rainfall in June 2018 (Fig. 2) had values greater than $100 \mathrm{~mm}$ in most regions of the country. The largest quantities, more than $150 \mathrm{~mm}$, were recorded mainly in hill and mountain areas. 


\section{RESULTS}

Hydrology International Dictionary defines "flood" as an increase, in a relatively short time, of the water level of an river to a peak, where the water level returns to a slower pace (WMO, 2011). The flow variation of the Trotuș River at the five analyzed hydrometric stations are plotted as graph (Fig. 3) and also the characteristic elements of the flood waves produced on 30 June 2018 are shown below.
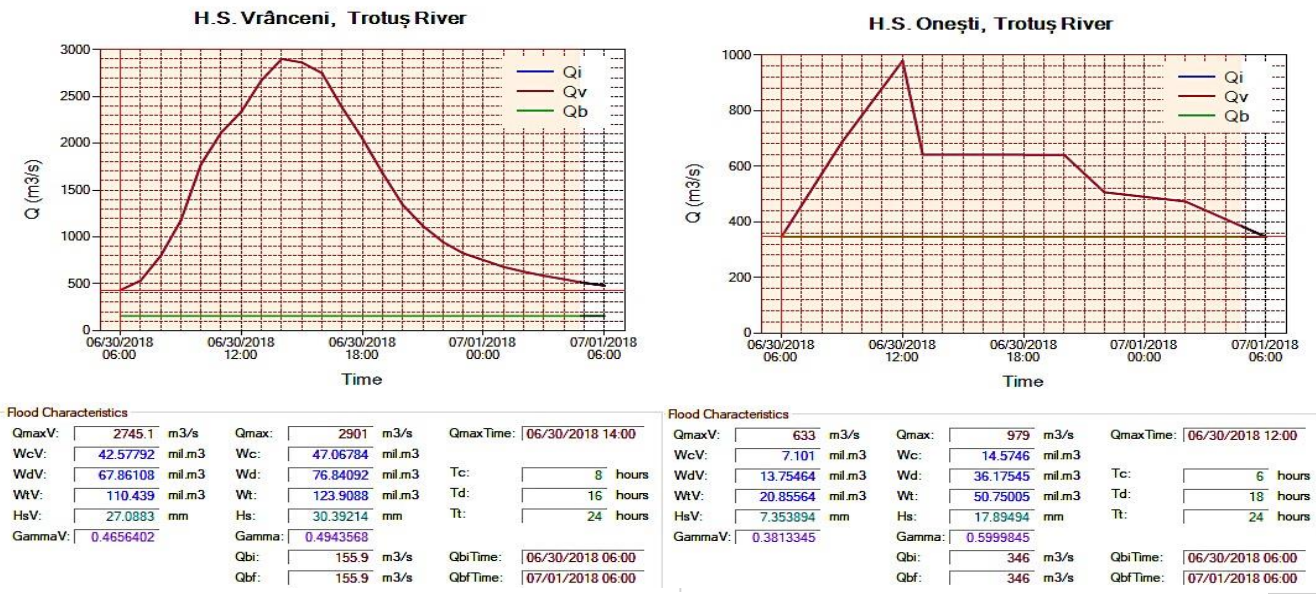

H.S. Goioasa, Trotuș River

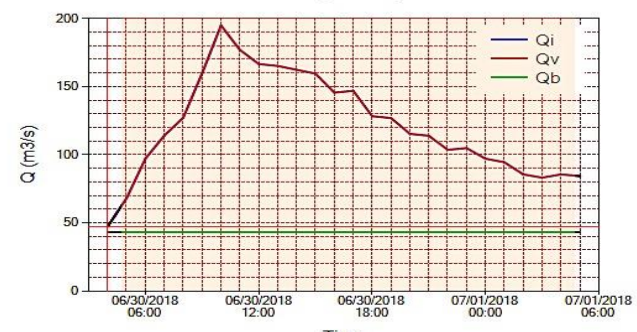

Time
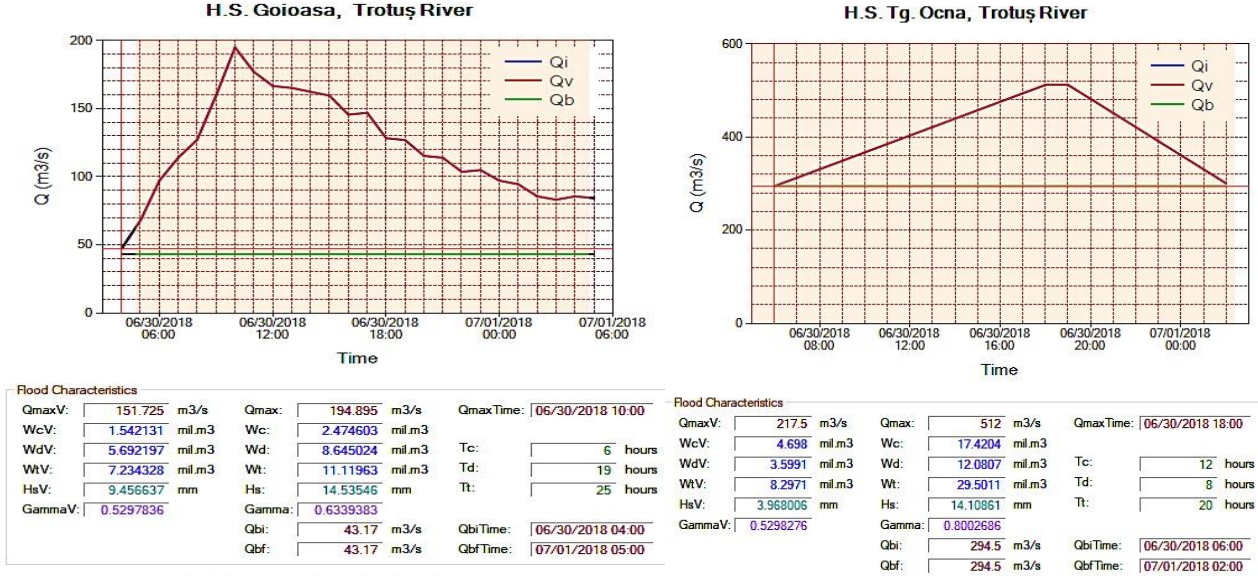

H.S. Lunca de Sus, Trotuş River

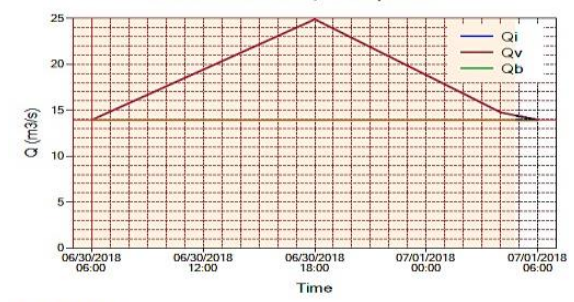

Fig. 3. Characteristic elements of the flood waves produced on 30 June 2018, Trotuș River basin, at five hydrometric

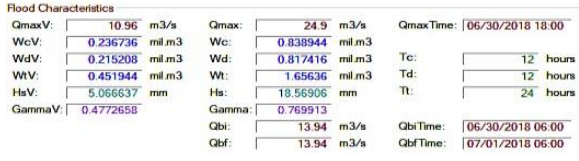
stations (data source: INHGA) 
Based on increased atmospheric instability and high soil moisure conditions, indicated both by the Radar products of the used systems and by the dedicated products for flash floods, significant quantities of precipitation were recorded in the hydrographic basin of Trotuş River on 30 June 2018, with cores of approximately $100 \mathrm{~mm}$ (Fig. 2).

These have led to the exceeding of the danger level on the Trotuş river at Vrânceni hydrometric station $(\mathrm{CP}+20 \mathrm{~cm})$ and of the flood level at the Oneşti hydrometric station $(\mathrm{CI}+60 \mathrm{~cm})$ and Lunca de Sus hydrometric station $(\mathrm{CI}+30 \mathrm{~cm})$ (Fig. 3). Following the occurrence of this event, significant damage was recorded.

The radar products of the SEEFFG system and the national ROFFG system indicated the possibility of accumulation of significant amounts of precipitation in the study area and the imminence of flash flood discharge in small hydrographic basins related to it (Fig. 4 and Fig. 5).

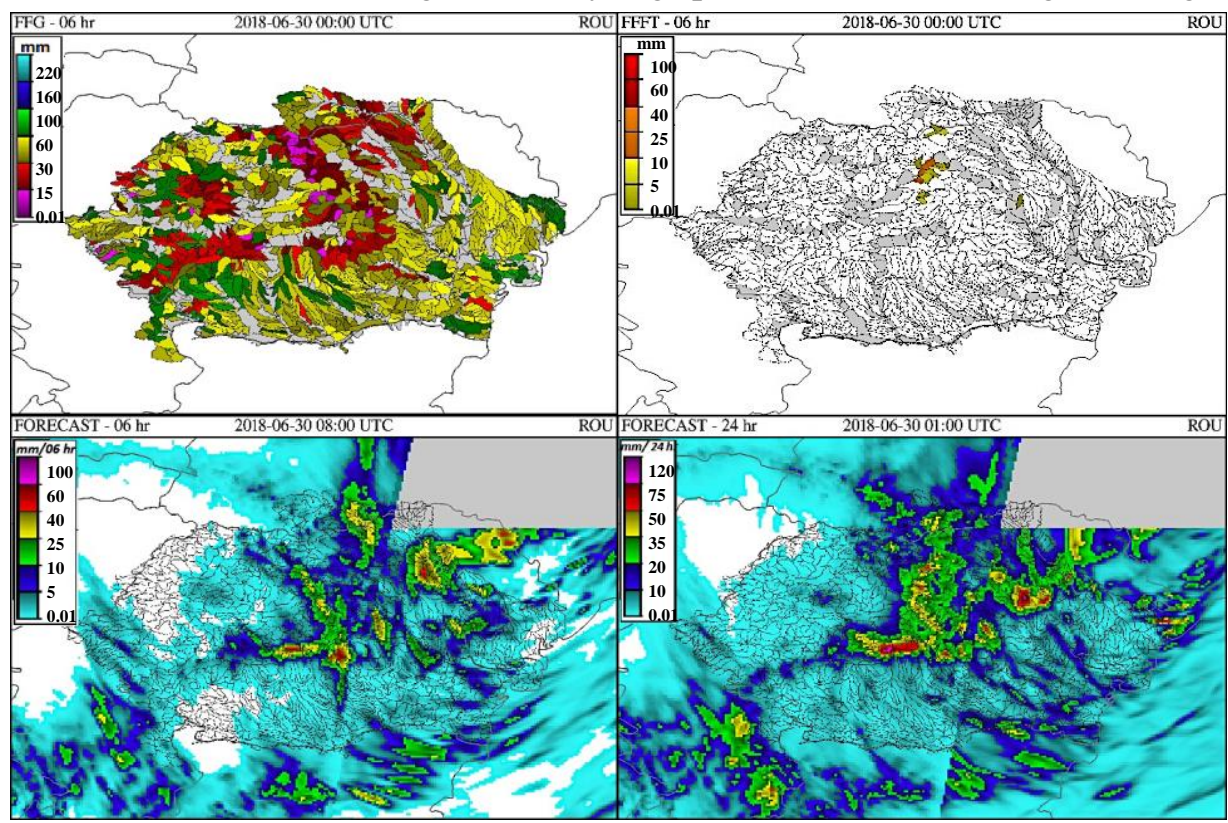

Fig. 4. SEEFFG products - national level (data source: INHGA)

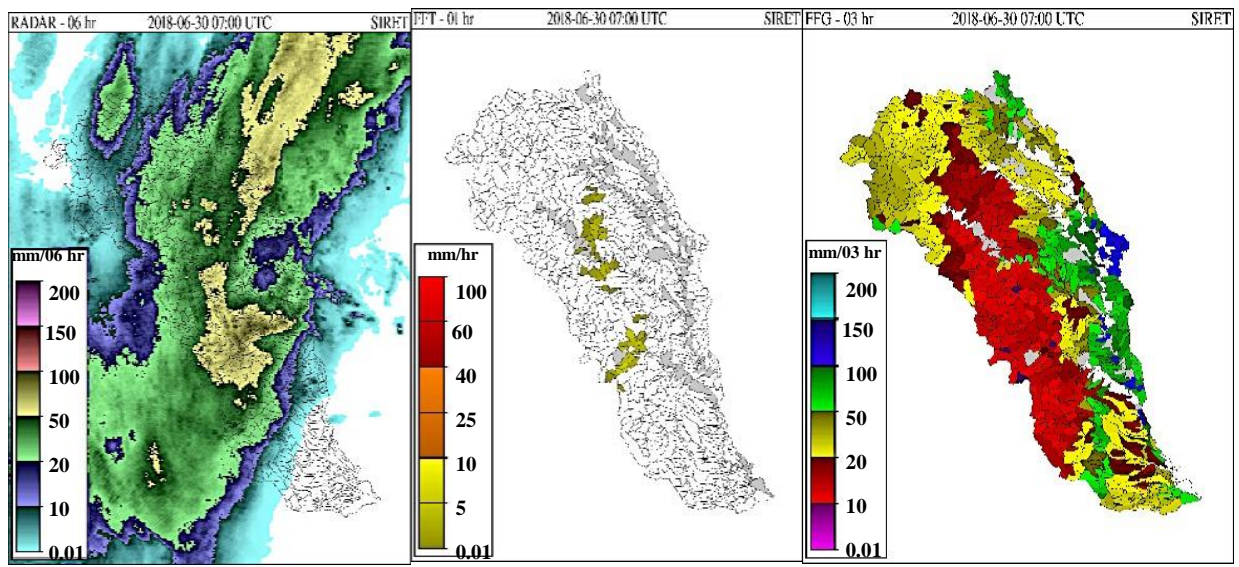

Fig. 5. ROFFG products - Siret River basin (data source: INHGA) 
At that time, the specific products provided by the EFAS system indicated the possibility of floods in the Trotus River basin, as shown in Fig. 6 and Fig. 7.

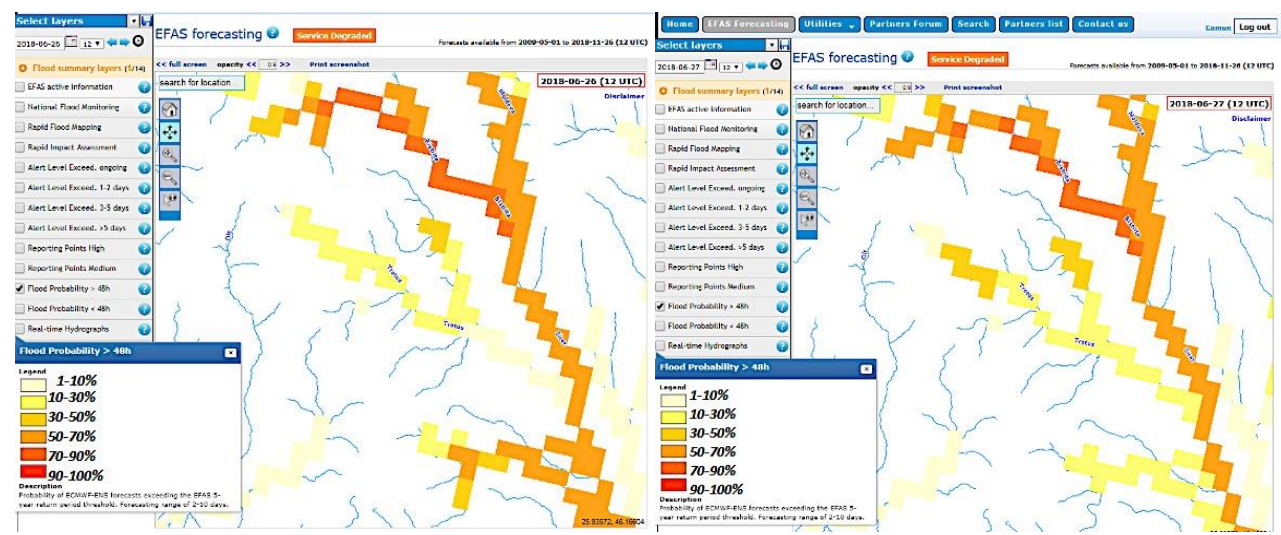

Fig. 6. Flood probability > 48hr (26-27.06.2018 - 12 utc) (data source: INHGA)

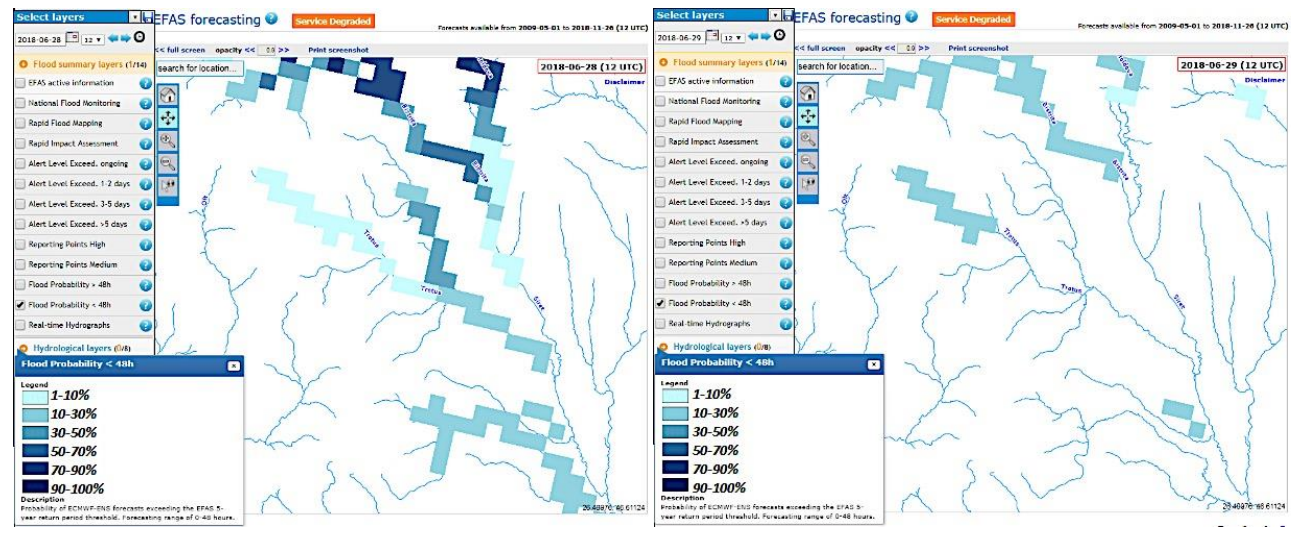

Fig. 7. Flood probability < 48hr (28-29.06.2018 - 12 utc) (data source: INHGA)

\section{CONCLUSIONS}

Floods are dangerous hydrometeorological events, resulting from excess rainfall, being considered natural disasters, that affect society and the environment, causing direct or indirect economic damages (Stănescu, V., Drobot, R., 2002)

The event produced on 30 June 2018 in the Trotuş River basin was anticipated by all three forecasting systems used in the operative activity. The radar product of the ROFFG and SEEFFG system reported uniform precipitation amounts over the entire surface with cores of approximately $35-50 \mathrm{~mm} / 24$ hour for the study area. Also, FFG, the main product of the ROFFG system, indicates the total volume of rainfall over the given duration which is just enough to cause bankfull flow at the outlet of the draining stream. indicates low values. At the same time, the product of 
estimating the possibility of producing rapid floods - FFT (Flash flood threat) indicates high values. With regard to the EFAS system, both products dedicated to flash floods suggest a great potential for producing a rapid flood in the Trotuş catchment area. Consequently, based on this information, INHGA issued orange code warning messages on 29 and 30 June 2018, at national level (Fig. 9) and local level (Fig. 10) targeting this high-risk area, and then this event would be confirmed on the basis of damage reports received from the territory.

The national meteorological administration has also issued an orange code warning that targets this area (Fig. 8)
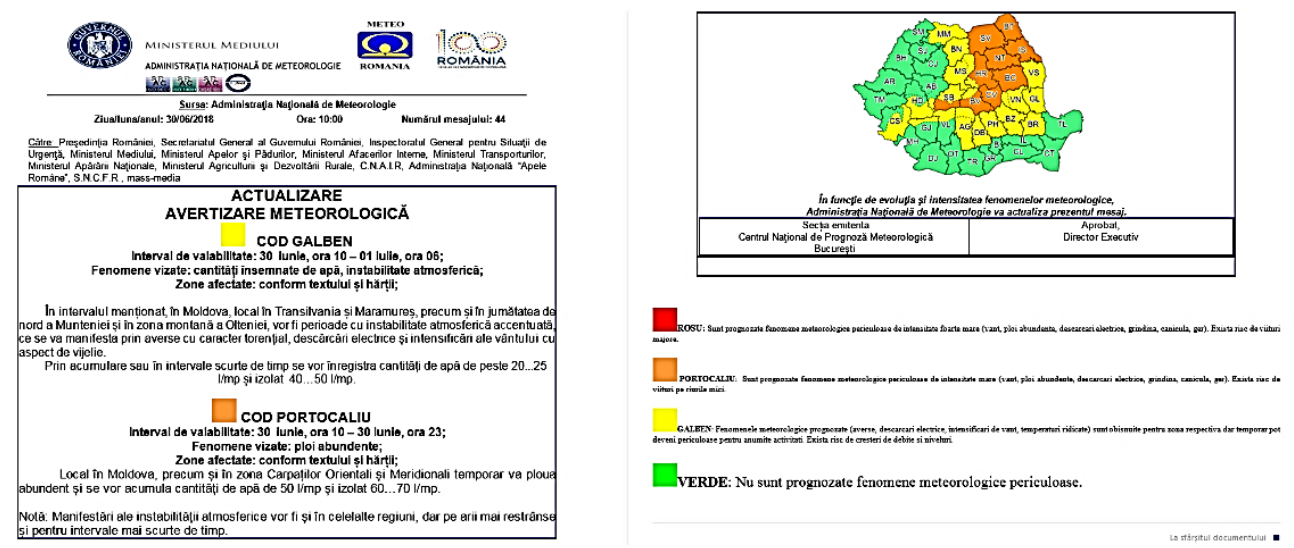

Fig. 8. Meteorological warning at national level no. 44 - 30.06.2018 (data source: INHGA)

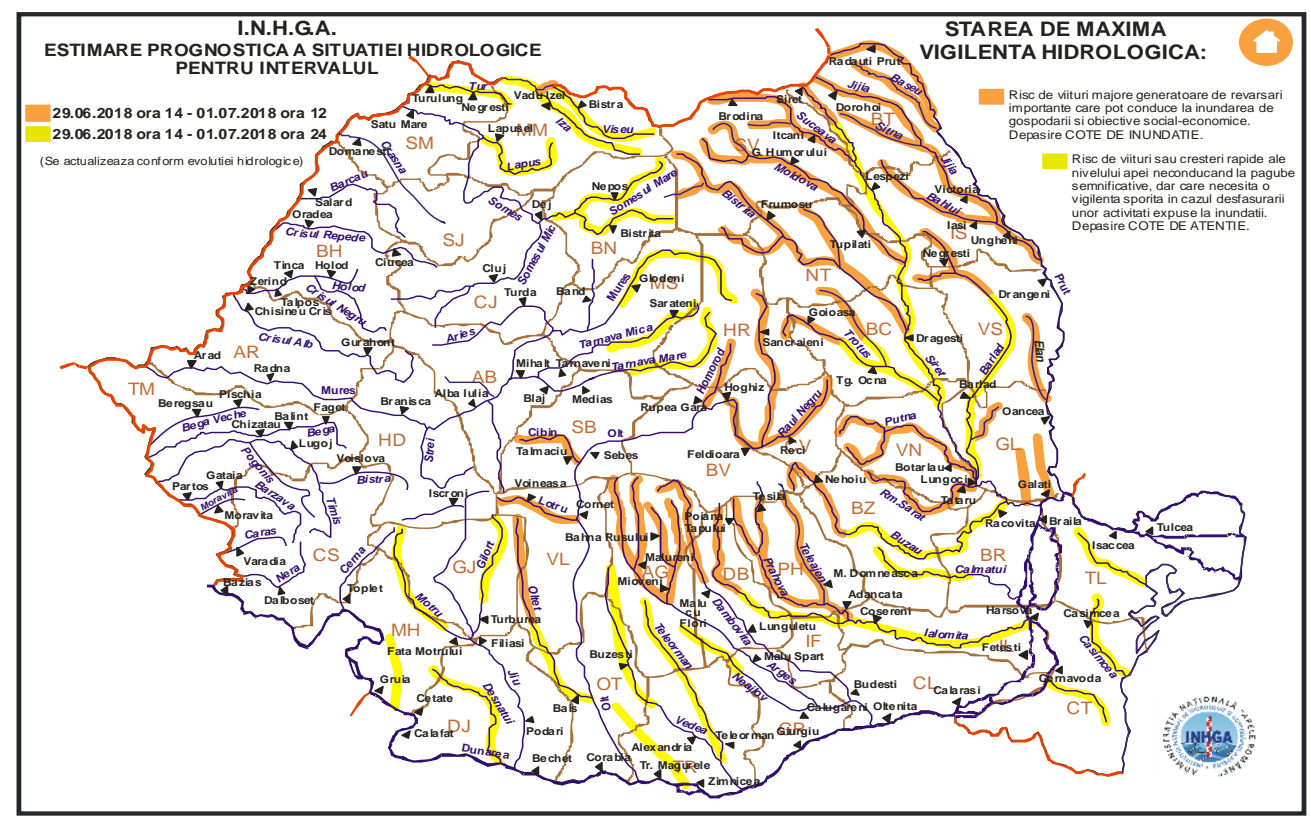

Fig. 9. Hydrological warning at national level no. 41 - 29.06.2018

(data source: INHGA) 


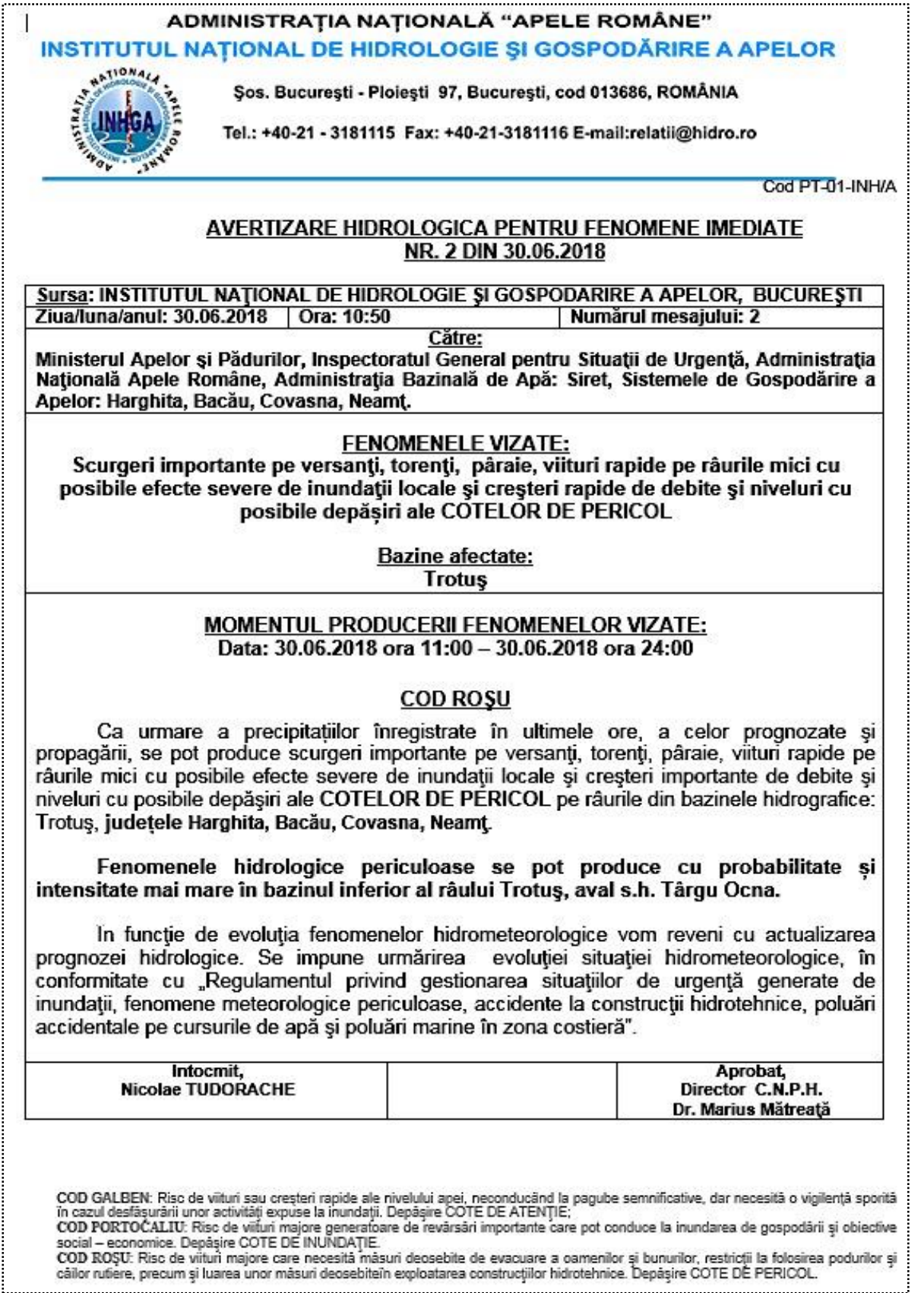

Fig. 10 - Hydrological warning, Trotuș River basin, no. 2 - 30.06.2018 (data source: INHGA)

The maximum flow impact on society is primarily reflected in material assets, with the negative effect of even loss of life. During floods the infrastructure (buildings, roads, railways, bridges etc.) is affected, the soil - by washing, erosion 
and sliding, water - by contamination. Social and economic activities are also affected, as well as transport and telecommunications.

On the basis of the operational report on the effects of the dangerous hydrometeorological phenomena produced during the analyzed period, there are there are hundreds of households flooded, 8 flooded houses, one isolated village due to a damaged bridge, tens of kilometers of flooded streets, 17 bridges, 34 damaged bridges, 1 destroyed bridge, 30 isolated families, a flooded wastewater treatment plant, 7 persons evacuated, 4 flooded economic targets, 40 dead birds, tens of hectares of flooded land, fountains, etc.

Among the causes that have led to these phenomena are mainly included torrential rainfall, leakage from the slopes, overflows.

Regarding the actions and interventions for diminishing the effects of the dangerous hydrometeorological phenomena undertaken by SGA Bacau it can be mentioned: stopping the floods caused by the Bârnat River, through elevation of banks in certain areas, in Călcâi village (Oituz village) ISU Bacau and CLSU Oituz, have acted for the execution of a temporary bridge.

\section{REFERENCES}

1. Ardelean, F., Colda, I. (2008) Cauzele schimbărilor climatice - un subiect controversat, Conferința a XV-a Eficiență, Confort, Conservarea Energiei şi Protecția Mediului, Facultatea de Instalații, Bucureşti.

2. Pișota, I., Zaharia, L., Diaconu, D. (2005) Hidrologie, Ed. Univeristară, București

3. Roşu, Al. (1973), Geografia Fizică a României, Ed. Didactică şi Pedagogică, Bucureşti

4. Solomon, S., et al., (2009) Irreversible climate change due to carbon dioxide emissions. Proceedings of the national academy of sciences 106.6: 1704-1709.

5. Stănescu, V., Dobrot, R. (2002) Măsuri nestructurale de gestiune a inundaţiilor, Ed. ${ }^{*} \mathrm{H} * \mathrm{G} * \mathrm{~A}$, Bucureşti

6. Trenberth, K. E., et al., (2007) Observations: surface and atmospheric climate change. Chapter 3 . Climate change : 235-336.

7. WMO (2011), Manual on flood forecasting and warning

8. *** (1971) Râurile României. Monografie hidrologicăa, IMH, București

9. *** (1992) Atlasul Cadastrului apelor din România, partea I - date morfo-hidrologice asupra rețelei hidrografice de suprafață, Ministerul Mediului Aqaproiect S.A, București 